\section{Phase II validation study of the rK39 ELISA prototype for the diagnosis of canine visceral leishmaniasis in Brazil}

\author{
Estudo de validação da fase II do teste ELISA rK39 \\ para o diagnóstico da leishmaniose visceral \\ canina no Brasil
}

\section{Estudio de validación de la fase II del test ELISA rK39 para el diagnóstico de la leishmaniasis visceral canina en Brasil}

\author{
Fernanda Alvarenga Cardoso Medeiros 1 \\ Job Alves de Souza Filho 1 \\ José Ronaldo Barbosa 1 \\ Lucas Edel Donato 2 \\ Fabiano Borges Figueiredo 3 \\ Guilherme Loureiro Werneck 4 \\ Gustavo Fontes Paz 5 \\ Mayerson Thompson 6 \\ Andreza Pain Marcelino 7
}

\begin{abstract}
Dogs are the main reservoirs in the domestic transmission cycle of visceral leishmaniasis, and the diagnosis is essential for the effectiveness of the control measures recommended by the Brazilian Ministry of Health. We assessed the diagnostic performance of the ELISA-Vetlisa/BIOCLIN prototype with serum samples from 200 dogs, in triplicate, including symptomatic, oligosymptomatic, asymptomatic, and healthy dogs, originated by two distinct panels ( $A$ and $B$ ) characterized by parasitological tests as the reference standard. In this study, the prototype kit showed a 99\% sensitivity (95\%CI: 94.5-100.0) and a 100\% specificity (95\% CI: 96.4-100.0). The sensitivity of the prototype kit did not vary significantly with the clinical status of the dogs. Considering the final result classification (positive or negative), agreement between the results of repeated tests was almost perfect (kappa $=0.99$; 95\%CI: 0.98-1.00). ELISAVetlisa/BIOCLIN is a promising option for the serological diagnosis of canine visceral leishmaniasis in Brazil.
\end{abstract}

Enzyme-Linked Immunosorbent Assay; Visceral Leishmaniasis;

Dogs; Diagnosis

\author{
Correspondence \\ A. P. Marcelino \\ Instituto Nacional de Infectologia Evandro Chagas, Fundação \\ Oswaldo Cruz. \\ Av. Brasil 4365, Rio de Janeiro, RJ 20941-150, Brasil. \\ andreza.marcelino@ini.fiocruz.br \\ ${ }^{1}$ Fundação Ezequiel Dias, Belo Horizonte, Brasil. \\ 2 Ministério da Saúde, Brasília, Brasil. \\ 3 Instituto Carlos Chagas, Fundação Oswaldo Cruz, Curitiba, \\ Brasil. \\ 4 Instituto de Medicina Social, Universidade do Estado do Rio de \\ Janeiro, Rio de Janeiro, Brasil. \\ 5 Instituto René Rachou, Fundação Oswaldo Cruz, Belo \\ Horizonte, Brasil. \\ 6 Universidade Federal de Minas Gerais, Belo Horizonte, Brasil. \\ 7 Instituto Nacional de Infectologia Evandro Chagas, Fundação \\ Oswaldo Cruz, Rio de Janeiro, Brasil.
}




\section{Introduction}

Visceral leishmaniasis (VL) is a neglected tropical disease caused by protozoan parasites of the genus Leishmania. Brazil is one of the six countries where more than $90 \%$ of cases of this disease occur ${ }^{1}$. In the Americas, VL is caused by Leishmania infantum, transmitted by the bite of phlebotomine vectors, mainly Lutzomyia longipalpis 2, and dogs are the main urban reservoirs 3 . Control measures include early diagnosis and treatment of human cases, reactive chemical vector control, education activities, and control of the canine reservoir. In this context, accurate serological diagnosis of canine visceral leishmaniasis (CVL) is of major importance.

Since 2011, the Brazilian VL control program recommends screening CVL with an immunochromatographic test (ICT) followed by the ELISA assay as confirmatory test 4 . Since then, public laboratories use the ICT Dual Path Platform rK28 (DPP CVL, Bio-Manguinhos, Rio de Janeiro, Brazil), followed by ELISA with soluble Leishmania major antigen (Bio-Manguinhos). Despite the improvement of the diagnosis, debate on the accuracy of this protocol persists 5,6. Moreover, the limited supply of diagnostic kits for ELISA in Brazil represents a problem, mainly for private laboratories.

The recombinant protein $\mathrm{rK} 39$, derived from a specific antigen produced by Leishmania donovani complex species, has been widely studied in the last decades for use in the serological diagnosis of VL, presenting varied performance, especially in rapid tests $7,8,9,10,11,12$.

In this context, the company BIOCLIN developed a commercial ELISA kit using rK39 as antigen (Vetlisa/BIOCLIN, Belo Horizonte, Brazil). However, at the moment, reference centers in Brazil have not assessed commercial ELISA rK39 LVC kits. This study evaluated the performance of this prototype in a sample of dogs, using a well-defined reference standard and blind analysis for the diagnosis of CVL in infected and non-infected dogs from endemic areas of Brazil.

\section{Methods}

\section{Animals and local study}

This study was a retrospective diagnostic test evaluation, with samples previously collected in two studies (panel A and B), kept under guard, and monitored using the serological panel database of the Parasitic Diseases Service, Ezequiel Dias Foundation (Minas Gerais State, Brazil).

In panel A, we assessed 1,440 serum samples obtained from dogs from the municipalities of Bauru (São Paulo State), Brasília (Federal District), Palmas (Tocantins State), and Fortaleza (Ceará State), between 2009 and 2010. In each selected municipality, three distinct, non-continuous neighborhoods with the highest prevalence of CVL were studied. Dogs were selected by active search, by house-tohouse visits, following a systematic sampling procedure. Inclusion criteria were dogs whose owners had lived in the study region for at least six months; dogs whose owners were of legal age and qualified to sign the informed consent form; dogs aged eight months and older; dogs in conditions of being submitted to sedation; and dogs without previous clinical evaluation or laboratory diagnosis for CVL. The exclusion criteria were pregnant female dogs; dogs that got aggressive with handling; stray dogs; and dogs undergoing anti-Leishmania chemotherapy.

In panel B, we assessed seventy-five serum samples obtained from dogs from the endemic municipality of Betim (Minas Gerais State) in 2015. The dogs were selected by active search by the Zoonoses Surveillance Unit (ZSU) of Betim or by the owners' spontaneously bringing the animals to ZSU. Inclusion criteria were dogs whose owners resided in the study region; dogs whose owners were of legal age and qualified to sign the informed consent form; dogs aged four months and older; dogs in conditions of being submitted to sedation and dogs a with previous serological diagnosis for CVL (ICT Dual Path Platform rK28 and ELISA/Bio-Manguinhos). Exclusion criteria were dogs that got aggressive with handling, dogs undergoing any anti-Leishmania chemotherapy.

In both panels, veterinarians performed clinical evaluation. Clinical conditions among symptomatic animals were heterogeneous. The dogs were classified as asymptomatic (absence of clinical signs), oligosymptomatic (the presence of one to three clinical signs), and symptomatic if the animals pre- 
sented typical signs of CVL (alopecia, dermatitis, conjunctivitis, lymphadenopathy, onychogryphosis, etc.) as adapted from criteria proposed by Mancianti et al. 13 .

\section{Reference standard tests}

In panel A, fragments of healthy skin and, when present, of skin lesions were collected for parasitological culture, immunohistochemistry, and histopathology according to the protocol proposed by Madeira et al. 14 and Menezes et al. 15. The parasites isolated in culture were characterized by isoenzymes based on protocols defined by Cupolillo et al. ${ }^{16}$. The characterization was performed to determine the species of Leishmania in each case and to positively identify cases of L. infantum.

In panel B, fragments of healthy skin, popliteal lymph node, and bone marrow aspirates were collected for parasitological culture and direct exams. Moreover, postmortem immunohistochemistry and polymerase chain reaction (PCR) for Leishmania sp. kDNA were performed according to the protocol proposed by Tafuri et al. 17 and Volpini et al. 18, respectively. The molecular characterization by restriction fragment length polymorphism (RFLP) was performed in the DNA samples to identify the L. infantum DNA.

\section{Study design, sample size, and test procedures}

A total of 200 serum samples were selected at random in the respective panels (100 positive and 100 negative), considering $90 \%$ sensitivity and $90 \%$ specificity with $\pm 6 \%$ error 19 . Positive samples were those with at least one positive parasitological test, and negative samples were those negative in all parasitological and serological tests. A total of 148 samples from panel A (6 asymptomatic, 13 oligosymptomatic, 29 symptomatic, and 100 negative samples) and 52 positive samples (11 asymptomatic, 10 oligosymptomatic, and 31 symptomatic) of panel B were used (Figure 1 and Supplementary Material. Box S1. http://cadernos.ensp.fiocruz.br/static//arquivo/suppl-e000413-20_9739.pdf). After sample selection, two aliquots of 100 microliters of each sample were taken from the freezer $-80^{\circ} \mathrm{C}$. The samples were coded with a sequential and unambiguous number for each of them, from 1 to 200 , by an analyst who did not participate in the execution of the Vetlisa/BIOCLIN tests.

The test was performed according to the manufacturer's instructions, considering the cutoff $=$ negative control mean absorbance +0.5 and calculating the index by dividing the absorbance of the sample by the cutoff value. All samples were tested in triplicate.

\section{Statistical analysis}

Accuracy evaluation was based on the cross-distribution of positive (asymptomatic, oligosymptomatic, and symptomatic) and negative samples, as detected by the reference standard, and the results of the Vetlisa/BIOCLIN test results of the 200 samples. Indeterminate results were excluded from the statistical analysis. We estimated sensitivity, specificity, and global accuracy with their respective $95 \%$ confidence intervals (95\%CI).

Reliability was assessed in three ways, considering the "index values". First, the intra-assay precision (repeatability) was performed in five replicates in a single run to detect antibodies of Leishmania, using seven positive and seven negative samples 20 . Second, the inter-assay precision (reproducibility) was assessed using the same samples used in repeatability analysis but now repeated for five consecutive days. Both the intra-assay (repeatability) and the inter-assay (reproducibility) precision levels were evaluated using the variation coefficient $(\mathrm{Vc})$ of the results of the retested samples using the equation: $\mathrm{Vc}=$ standard deviation/mean $\times 100$. Third, agreement between three repeated measures of the "index values" for all samples was estimated by the intraclass correlation coefficient (ICC) using a two-way mixed-effects model 21,22. Agreement was also assessed using the kappa statistic considering the results of the Vetlisa/BIOCLIN test classified as positive (asymptomatic, oligosymptomatic, and symptomatic) and negative.

The results readings were individually assessed using the Shapiro-Wilk normality test and compared using the Kruskal-Wallis test. The groups (asymptomatic, oligosymptomatic, and symptomatic) 


\section{Figure 1}

Sample selection flowchart.
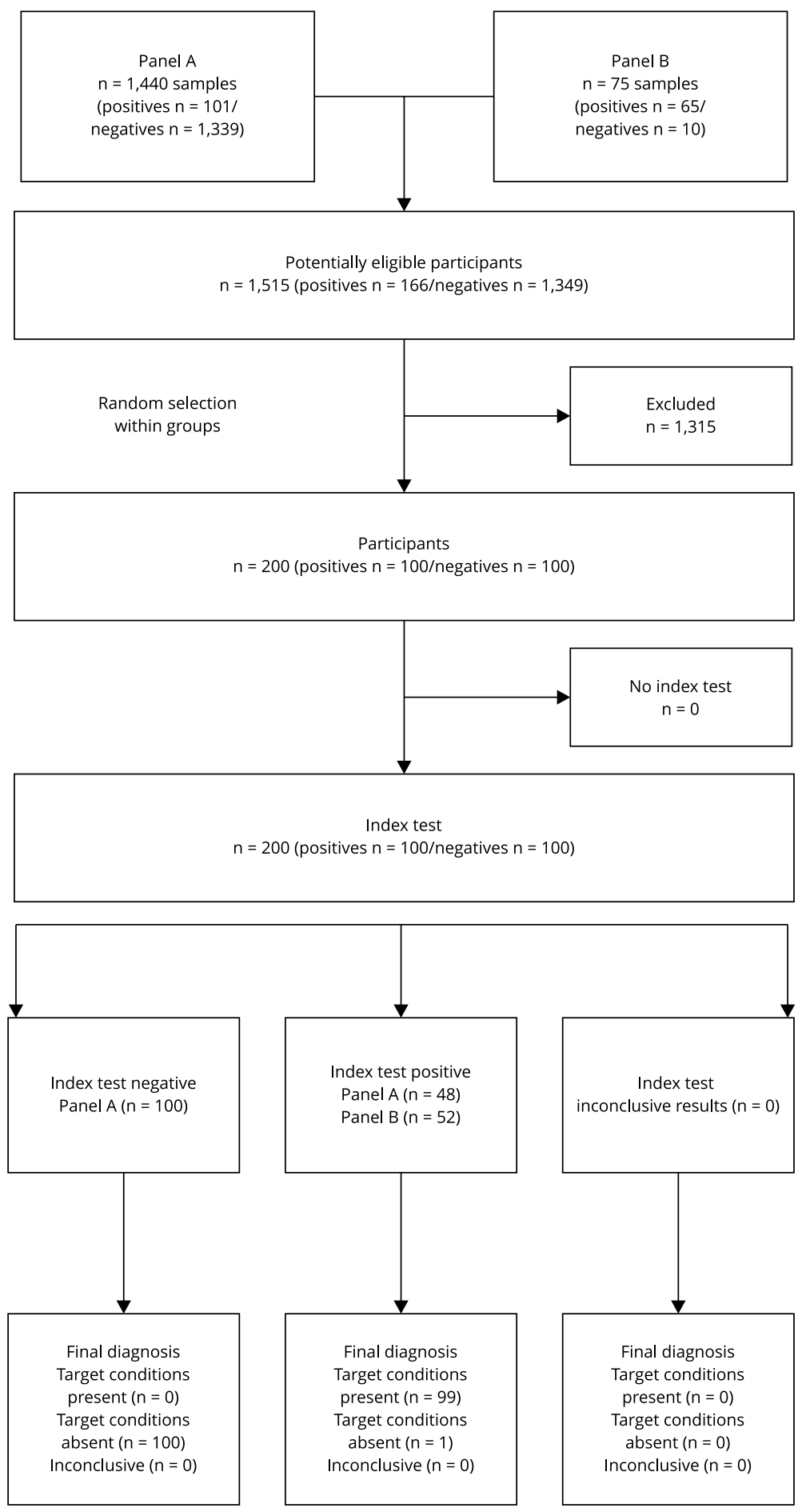
were compared using the Tukey and Kramer (Nemenyi) test. All statistical procedures were performed using R (http://www.r-project.org) and Stata software (https://www.stata.com).

\section{Ethics}

The study was approved by the Animal Ethics Committee of the Ezequiel Dias Foundation (n. 016/18).

\section{Results}

The Vetlisa/BIOCLIN test was performed in triplicate. All final classifications (positive or negative) were consistent across the repetitions, except one, coming from an infected dog, in which one of the replicates was considered undetermined (the other two were positive). This result was discarded from the sensitivity and specificity analysis.

The Vetlisa/BIOCLIN test detected the presence of anti-Leishmania sp. antibodies in $99 \%$ of infected dogs included in this analysis (98/99). The only false negative was a symptomatic dog. In the group of negative dogs, all the samples presented negative results in all three replications of the Vetlisa/BIOCLIN test.

Table 1 shows an an accuracy performance of 99\% sensitivity (94.5-100.0) and 100\% specificity (96.4-100.0). Regarding the detection of different CVL clinical presentations, the test showed sensitivity values $(95 \% \mathrm{CI})$ of $100 \%, 100 \%$, and $98.3 \%$ for asymptomatic, oligosymptomatic, and symptomatic dogs.

Figure 2 shows the distribution of the Vetlisa/BIOCLIN test results as expressed by the "index values" for negative, asymptomatic, oligosymptomatic, and symptomatic dogs. We found no statistically significant difference between the asymptomatic, oligosymptomatic, and symptomatic, either when analyzed together $(\mathrm{p}=0.1874)$ or when analyzed separately (asymptomatic versus oligosymptomatic, $\mathrm{p}=1.00$; oligosymptomatic versus symptomatic, $\mathrm{p}=0.29$ ); and asymptomatic versus symptomatic, $\mathrm{p}=0.35$ ).

The intra-assay $\mathrm{Vc}$ ranged from $2.5 \%$ to $9.3 \%$ (mean $=4.6 \%$ ) for all fourteen samples; from $2.5 \%$ to $5.7 \%($ mean $=3.7 \%)$ for positive canine sera; and from $2.9 \%$ to $9.3 \%($ mean $=5.4 \%)$ for negative canine sera. For the reproducibility analyses (inter-assay precision), the variation coefficients were calculated for the results of five different assays performed on consecutive days with the samples evaluated. The reproducibility Vc ranged from $6.6 \%$ to $12 \%$ (mean $=8.8 \%$ ) for all fourteen samples; from $6.6 \%$ to $8.4 \%$ (mean $=7.5 \%)$ for positive canine sera; and from $7.9 \%$ to $12 \%($ mean $=10.1 \%)$ for negative canine sera.

As measured by the kappa statistic for the final classification provided by the test (positive or negative) for the three replications, agreement was almost perfect (kappa $=0.99 ; 95 \% \mathrm{CI}: 0.98-1.00)$. Agreement between three repeated measures of the "index values" for all samples was also almost perfect, as indicated by the intraclass correlation coefficient (ICC $=0.98$; 95\%CI: 0.98-0.99).

\section{Discussion}

The sensitivity and specificity of the diagnostic tests currently used in Brazil to assess CVL in the field, has been challenged due to their imperfect accuracy and, consequently, the impact on the effectiveness of control measures such as euthanasia of infected dogs $23,24,25$. The accuracy of serological tests may vary with the clinical status of infected dogs and according to the stage of infection or the immune status of the host 26 .

Our study provided evidence that the ELISA-Vetlisa/BIOCLIN prototype shows substantial sensitivity, specificity, and reproducibity. It is essential to point out that further studies regarding the specificity of this test are necessary, with the inclusion of positive samples for other pathogens.

In general, diagnostic tests based on recombinant protein are more specific than crude soluble antigens $27,28,29,30$. In 2015, a metanalysis with 15 studies reported $89 \%$ (95\%CI: 87-91) sensitivity and 87\% (95\%CI: 86-88) specificity, considering different ELISA with soluble antigens to diagnose CVL 31. 
Table 1

Accuracy performance of the Vetlisa/BIOCLIN prototype for canine visceral leishmaniasis.

\begin{tabular}{|c|c|c|c|}
\hline Clinical status & $\begin{array}{l}\text { Sensitivity } \\
\%(95 \% \mathrm{Cl})\end{array}$ & $\begin{array}{l}\text { Specificity } \\
\%(95 \% \mathrm{Cl})\end{array}$ & $\begin{array}{l}\text { Accuracy } \\
\%(95 \% \mathrm{Cl})\end{array}$ \\
\hline All valid samples $(n=199)$ & $99.0(94.5-100.0)$ & $100.0(96.4-100.0)$ & $99.5(97.2-100.0)$ \\
\hline Only infected asymptomatic $(n=17)$ & $100.0(80.5-100.0)$ & NA & NA \\
\hline Only infected oligosymptomatic $(n=23)$ & $100.0(85.2-100.0)$ & NA & NA \\
\hline Only infected symptomatic $(n=60)$ & $98.3(90.9-100.0)$ & NA & NA \\
\hline
\end{tabular}

95\%Cl: 95\% confidence interval; NA: not applicable.

\section{Figure 2}

ELISA results (absorbance/cut-off 450nm) in negative and positive canine sera with different clinical status.

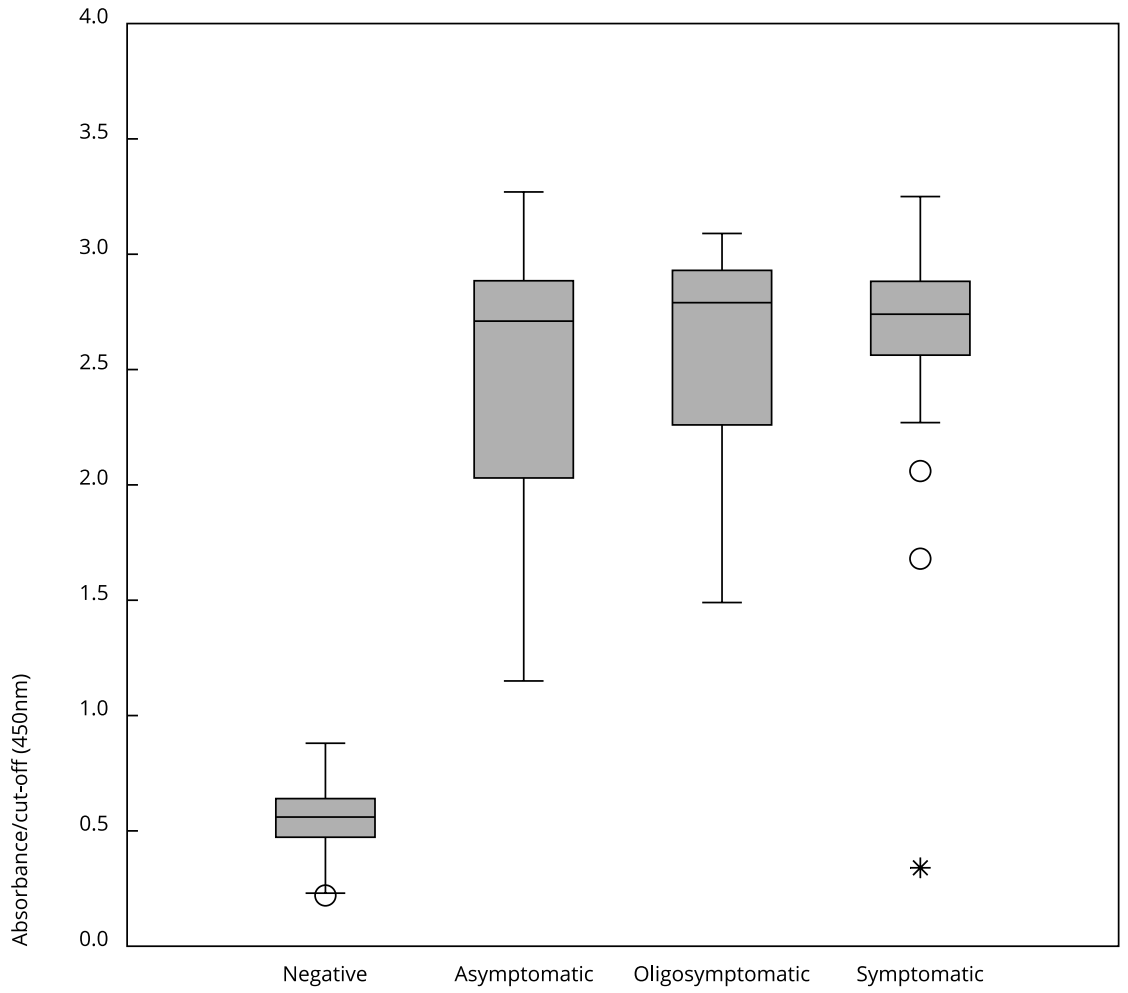

Conversely, studies with rK39 antigens of L. infantum demonstrated performance results with sensitivity ranging from $59 \%$ to $100 \%$ (depending on the disease stage) and specificity from $85 \%$ to $98 \% 9,32$.

Venturin et al. 33 found $97 \%$ sensibility and $95 \%$ specificity for in-house rK39 antigen-based ELISA using a panel of dogs characterized with a direct examination in lymph node aspirate. Nevertheless, we should consider that the specificity might be underestimated in panels characterized with only lymph node aspirate because of the low sensitivity of the direct examination in this type of sample. Other authors observed contradictory values of sensibility and specificity when using ELISA rK39. 
Santarém et al. 34 found values of sensitivity of $88 \%$ in symptomatic and $56 \%$ in asymptomatic animals when using ELISA rK39. Teixeira et al. 35 observed sensitivity and specificity of 37\% (95\%CI: 27-49) and $83 \%$ (95\%CI: 71-91) respectively. The choice of the reference standard, which included both conventional parasitological techniques and a combination of molecular tests in blood and bone marrow samples, might have influenced the results in the previous study. Variations in the results may also be a consequence of the quality of the diagnostic kit. For this study, we developed the diagnostic kit in an industrial setting. We used panels with different parasitological tests that guarantee the designated values of the samples and represent different transmission contexts of Brazil. However, we previously tested panel B using conventional serological tests, which may have contributed to overestimating the test performance. Additionally, the lack of the simultaneous application of the prototype evaluation and the standard reference tests may have also influenced the result.

In a preliminary test performed by the Vetlisa/BIOCLIN, the prototype showed promising sensitivity and specificity values of $96.8 \%$ and $98.9 \%$, respectively, similar to those obtained in this study, a 99\% sensitivity (95\%CI: 94.5-100.0) and a 100\% specificity (95\%CI: 96.4-100.0) (Quibasa-BIOCLIN. https://quibasa.bioclin.com.br/anexos/INSTRUCOES_VETLISA\%20LEISHMANIOSE\%20IgG_ TRILINGUE.pdf, accessed on 18/Dec/2019).

Dogs that develop signs of CVL have typically high serum antibody titers and, consequently, sensitivity antibody-based tests are unlikely to be similar for asymptomatic and symptomatic infections 36,37. However, due to the progression of VL itself, it may cause immunosuppression and decrease antibody titers in individuals at advanced stages of the disease 38 . Thus, positive rK39 rapid diagnostic test results are strongly associated with high infection levels and disease progression $39,40,41$. On the other hand, other authors demonstrate that asymptomatic dogs can also present high parasitism 42,43 , not necessarily related to a lower immune response 44 . Concerning the sensitivity and specificity results, we found no statistical difference between the clinical groups. Despite the small sample of asymptomatic dogs, the results are promising.

The epidemiological role of asymptomatic dogs in the maintenance of the disease is still a matter of discussion, and many authors believe that the success of VL control measures relates to the effective diagnosis of asymptomatic dogs $34,35,39,45$. In this sense, it is auspicious to have a test such as the one evaluated in this study, in which the results are not substantially affected by the clinical status of infected dogs.

In Brazil, specificity is a crucial characteristic for ELISA because it is a confirmatory test. Considering the standardized antigens to improve the reproducibility of results in different Brazil regions, it is critical to implement and analyze validation studies on diagnostic tests for CVL.

\section{Conclusions}

Our study shows that Vetlisa/BIOCLIN prototype might be a promising option in association with other methods for diagnosing CVL. Nevertheless, a prospective phase III study is still required, using simultaneous assessments between standard reference tests and the rK39 ELISA in dogs from endemic areas. A more comprehensive range of diagnostic test options is essential for private laboratories and veterinary services in Brazil, given the increasing demand and public health impact. 


\section{Contributors}

F. A. C. Medeiros gave substantial contributions to the conception and design of the study, analysis and interpretation of data for the worK, preparation of the worK and assistance in the review. J. A. Souza Filho contributed in the conception and design of the study, data interpretation and revision in the writing of the manuscript. J. R. Barbosa collaborated in the study design, execution of serological tests, data interpretation and revision in the writing of the manuscript. L. E. Donato, F. B. Figueiredo and G. F. Paz contributed on the interpretation of the data, assistance in making the serological panel available and revision in the writing of the manuscript. G. L. Werneck participated in data interpretation, statistical analysis and revision of the manuscript. M. Thompson gave assistance with ELISA's essay methodology and reviewed the manuscript. A. P. Marcelino participated in the conception and design of the study, analysis and interpretation of data, selection of the serological panel used and reviewed the final version of the manuscript.

\section{Conflict of interests}

During the period this study was carried out, the co-author M. Thompson worKed at the company responsible for developing the assessed diagnostic kit.

\section{Additional informations}

ORCID: Fernanda Alvarenga Cardoso Medeiros (0000-0003-4315-3114); Job Alves de Souza Filho (0000-0002-6592-2378); José Ronaldo Barbosa (0000-0003-1838-368X); Lucas Edel Donato (0000-0001-5600-7891); Fabiano Borges Figueiredo (0000-0001-6861-0997); Guilherme Loureiro Werneck (0000-0003-1169-1436); Gustavo Fontes Paz (0000-0002-5365-3393); Mayerson Thompson (0000-0002-1207-3042); Andreza Pain Marcelino (0000-0002-7197-2128).

\section{Acknowledgments}

The authors would like to thank Ezequiel Dias Foundation (Funed) for the support and infrastructure, and Oswaldo Cruz Foundation (Rio de Janeiro and Minas Gerais States), Brazilian Ministry of Health, and Zoonoses Surveillance Unit of Betim (Minas Gerais State) for all the assistance with sample collection and the characterization of panels. G. L. Werneck would like to thank the Brazilian National Research Council (CNPq) for the research productivity fellowship.

\section{References}

1. World Health Organization. Leishmaniasis. https://www.who.int/leishmaniasis/en/ (accessed on 05/Aug/2019).

2. Oliveira EF, Silva EA, Casaril AE, Fernandes CES, Paranhos Filho AC, Gamarra RM, et al. Behavioral aspects of Lutzomyia longipalpis (Diptera: Psychodidae) in urban area endemic for visceral leishmaniasis. J Med Entomol 2013; 50:277-84.

3. Werneck GL. Visceral leishmaniasis in Brazil: rationale and concerns related to reservoir control. Rev Saúde Pública 2014; 48:851-6.

4. Departamento de Vigilância das Doenças Transmissíveis, Secretaria de Vigilância em Saúde, Ministério da Saúde. Nota Técnica Conjunta no 01/2011-CGDT-CGLAB/ DEVIT/SVS/MS. Esclarecimentos sobre susbtituição do protocolo diagnóstico da leishmaniose visceral canina (LVC). Brasília: Ministério da Sáude; 2011.

5. Figueiredo FB, Vasconcelos TCB, Madeira MF, Menezes RC, Maia-Elkhoury ANS, Marcelino AP, et al. Validation of the Dual-Path Platform chromatographic immunoassay (DPP ${ }^{\circledR} \mathrm{CVL}$ rapid test) for the serodiagnosis of canine visceral leishmaniasis. Mem Inst Oswaldo Cruz 2018; 113:e180260.

6. Paz GF, Rugani JMN, Marcelino AP, Gontijo CMF. Implications of the use of serological and molecular methods to detect infection by Leishmania spp. in urban pet dogs. Acta Trop 2018; 182:198-201.

7. Bangert M, Flores-Chávez MD, Llanes-Acevedo IP, Arcones C, Chicharro C, García E, et al. Validation of rK39 immunochromatographic test and direct agglutination test for the diagnosis of Mediterranean visceral leishmaniasis in Spain. PLoS Negl Trop Dis 2018; 12:e0006277.

8. Mniouil M, Fellah H, Amarir F, Sadak A, Ettouys A, Bakri Y, et al. Comparative evaluation of immunochromatographic dipstick test (ICT) rK39, soluble antigen ELISA and IFAT for the sero-diagnosis of visceral leishmaniasis in Morocco. Acta Trop 2018; 182:185-9.

9. Quinnell RJ, Carson C, Reithinger R, Garcez LM, Courtenay O. Evaluation of rK39 rapid diagnostic tests for canine visceral leishmaniasis: longitudinal study and meta-analysis. PLoS Negl Trop Dis 2013; 7:e1992.

10. Vasconcelos RO, Michelin AF, Silveira Neto LS, Fattori KR, Lima VMF. Comparison between ELISA using total antigen and immunochromatography with antigen rK39 in the diagnosis of canine visceral leishmaniasis. Vet Parasitol 2010; 173:330-3.

11. Vesco G, Mignone W, Mondesire R, De Luna R, Simpson D, Oliva G, et al. Evaluation of the Leishmania recombinant $\mathrm{K} 39$ antigen as a diagnostic marKer for canine leishmaniasis and validation of a standardized enzyme-linked immunosorbent assay. Vet Parasitol 2002; 104:275-85. 
12. Burns JM, Shreffler WG, Benson DR, Ghalib HW, Badaro R, Reed SG. Molecular characterization of a kinesin-related antigen of Leishmania chagasi that detects specific antibody in African and American visceral leishmaniasis. Proc Natl Acad Sci U S A 1993; 90:775-9.

13. Mancianti F, Gramiccia M, Gradoni L, Pieri S. Studies on canine leishmaniasis control. 1. Evolution of infection of different clinical forms of canine leishmaniasis following antimonial treatment. Trans R Soc Trop Med Hyg 1988; 82:566-7.

14. Madeira MF, Schubach AO, Schubach TMP, Pereira SA, Figueiredo FB, Baptista C, et al. Post mortem parasitological evaluation of dogs seroreactive for Leishmania from Rio de Janeiro, Brazil. Vet Parasitol 2006; 138:366-70.

15. Menezes RC, Figueiredo FB, Wise AG, Madeira MF, Oliveira RV, Schubach TM, et al. Sensitivity and specificity of in situ hybridization for diagnosis of cutaneous infection by Leishmania infantum in dogs. J Clin Microbiol 2013; 51:206-11.

16. Cupolillo E, Grimaldi G, Momen H. A general classification of New World Leishmania using numerical zymotaxonomy. Am J Trop Med Hyg 1994; 50:296-311.

17. Tafuri WL, Santos RL, Arantes RME, Gonçalves R, Melo MN, Michalick MSM, et al. An alternative immunohistochemical method for detecting Leishmania amastigotes in paraffinembedded canine tissues. J Immunol Methods 2004; 292:17-23.

18. Volpini AC, Passos VM, Oliveira GC, Romanha AJ. PCR-RFLP to identify Leishmania (Viannia) braziliensis and L. (Leishmania) amazonensis causing American cutaneous leishmaniasis. Acta Trop 2004; 90:31-7.

19. Banoo S, Bell D, Bossuyt P, Herring A, Mabey D, Poole F, et al. Evaluation of diagnostic tests for infectious diseases: general principles. Nat Rev Microbiol 2006; 4(9 Suppl):S21-31.

20. Coordenação Geral de Acreditação. Orientação sobre validação de métodos analíticos: documento de caráter orientativo. http://www. inmetro.gov.br/Sidoq/Arquivos/CGCRE/ DOQ/DOQ-CGCRE-8_05.pdf (accessed on 18/May/2020).

21. Sim J, Wright CC. The kappa statistic in reliability studies: use, interpretation, and sample size requirements. Phys Ther 2005; 85:257-68.

22. Shrout PE, Fleiss JL. Intraclass correlations: uses in assessing rater reliability. Psychol Bull 1979; 86:420-8.

23. Costa DNCC, Codeço CT, Silva MA, Werneck GL. Culling dogs in scenarios of imperfect control: realistic impact on the prevalence of canine visceral leishmaniasis. PLoS Negl Trop Dis 2013; $7:$ :e2355.

24. Dantas-Torres F, Miró G, Bowman DD, Gradoni L, Otranto D. Culling dogs for zoonotic visceral leishmaniasis control: the wind of change. Trends Parasitol 2019; 35:97-101.
25. Pessoa-e-Silva R, Vaitkevicius-Antão V, Andrade TAS, Silva ACO, Oliveira GA, TrajanoSilva LAM, et al. The diagnosis of canine visceral leishmaniasis in Brazil: confronting old problems. Exp Parasitol 2019; 199:9-16.

26. Arruda MM, Figueiredo FB, Cardoso FA, Hiamamoto RM, Brazuna JCM, Oliveira MRF, et al. Validity and reliability of enzyme immunoassays using Leishmania major or L. infantum antigens for the diagnosis of canine visceral leishmaniasis in Brazil. PLoS One 2013; 8:e69988.

27. Burns JM, Madureira C, Freire M, Benson D, Pedral-Sampaio D, Badaro R, et al. rK39: a cloned antigen of Leishmania chagasi that predicts active visceral leishmaniasis. J Infect Dis 2011; 173:758-61.

28. Passos S, Carvalho LP, Orge G, Jerônimo SM, Bezerra G, Soto M, et al. Recombinant Leishmania antigens for serodiagnosis of visceral leishmaniasis. Clin Diagn Lab Immunol 2005; 12:1164-7.

29. Rosário EY, Genaro O, França-Silva JC, Costa RT, Mayrink W, Reis AB, et al. Evaluation of enzyme-linked immunosorbent assay using crude Leishmania and recombinant antigens as a diagnostic marKer for canine visceral leishmaniasis. Mem Inst Oswaldo Cruz 2005; 100:197-203.

30. Sanchez MCA, Celeste BJ, Lindoso JAL, Fujimori M, Almeida RP, Fortaleza CMCB, et al. Performance of rK39-based immunochromatographic rapid diagnostic test for serodiagnosis of visceral leishmaniasis using whole blood, serum and oral fluid. PLoS One 2020; 15:e0230610.

31. Peixoto HM, Oliveira MRF, Romero GAS. Serological diagnosis of canine visceral leishmaniasis in Brazil: systematic review and meta-analysis. Trop Med Int Health 2015; 20:334-52.

32. Mohapatra TM, Singh DP, Sen MR, Bharti $\mathrm{K}$, Sundar S. Comparative evaluation of rK9, rK26 and rK39 antigens in the serodiagnosis of Indian visceral leishmaniasis. J Infect Dev Ctries 2010; 4:114-7.

33. Venturin GL, Bragato JP, Silva KLO, Lima VMF. Recombinant K28 antigen in ELISA in the diagnosis of canine visceral leishmaniosis. Parasite Immunol 2015; 37:670-3.

34. Santarém N, Silvestre R, Cardoso L, Schallig H, Reed SG, Cordeiro-da-Silva A. Application of an improved enzyme-linked immunosorbent assay method for serological diagnosis of canine leishmaniasis. J Clin Microbiol 2010; 48:1866-74.

35. Teixeira AIP, Silva DM, Vital T, Nitz N, Carvalho BC, Hecht M, et al. Improving the reference standard for the diagnosis of canine visceral leishmaniasis: a challenge for current and future tests. Mem Inst Oswaldo Cruz 2019; 114:e180452. 
36. Santos ARR, Serufo AV, Figueiredo MM, Godoi LC, Vitório JG, Marcelino AP, et al. Evaluation of three recombinant proteins for the development of ELISA and immunochromatographic tests for visceral leishmaniasis serodiagnosis. Mem Inst Oswaldo Cruz 2019; 114:e180405.

37. Lemos EM, Laurenti MD, Moreira MAB, Reis $\mathrm{AB}$, Giunchetti RC, Raychaudhuri S, et al. Canine visceral leishmaniasis: performance of a rapid diagnostic test (Kalazar DetectTM) in dogs with and without signs of the disease. Acta Trop 2008; 107:205-7.

38. Rodrigues V, Cordeiro-da-Silva A, Laforge M, Silvestre R, Estaquier J. Regulation of immunity during visceral Leishmania infection. Parasit Vectors 2016; 9:118.

39. Duthie MS, Lison A, Courtenay O. Advances toward diagnostic tools for managing zoonotic visceral leishmaniasis. Trends Parasitol 2018; 34:881-90.

40. França-Silva JC, Costa RT, Siqueira AM, Machado-Coelho GLL, Costa CA, Mayrink W, et al. Epidemiology of canine visceral leishmaniosis in the endemic area of Montes Claros municipality, Minas Gerais State, Brazil. Vet Parasitol 2003; 111:161-73.
41. Porrozzi R, Costa MVS, Teva A, Falqueto A, Ferreira AL, Santos CD, et al. Comparative evaluation of enzyme-linked immunosorbent assays based on crude and recombinant leishmanial antigens for serodiagnosis of symptomatic and asymptomatic Leishmania infantum visceral infections in dogs. Clin Vaccine Immunol 2007; 14:544-8.

42. Laurenti MD, Rossi CN, Matta VLR, Tomokane TY, Corbett CEP, Secundino NFC, et al. Asymptomatic dogs are highly competent to transmit Leishmania (Leishmania) infantum chagasi to the natural vector. Vet Parasitol 2013; 196:296-300.

43. Moshfe A, Mohebali M, Edrissian G, Zarei Z, Akhoundi B, Kazemi B, et al. Canine visceral leishmaniasis: asymptomatic infected dogs as a source of $L$. infantum infection. Acta Trop 2009; 112:101-5.

44. Laranjeira DF, Matta VLR, Tomokane TY, Marcondes M, Corbet CEP, Laurenti MD. Serological and infection statuses of dogs from a visceral leishmaniasis-endemic area. Rev Saúde Pública 2014; 48:563-71.

45. Esteva L, Vargas C, Vargas de León C. The role of asymptomatics and dogs on leishmaniasis propagation. Math Biosci 2017; 293:46-55. 


\section{Resumo}

Os cães são os principais reservatórios do ciclo de transmissão domiciliar da leishmaniose visceral, e o diagnóstico é essencial para a efetividade das medidas de controle recomendadas pelo Ministério da Saúde. Os autores avaliam o desempenho diagnóstico do protótipo da ELISA-Vetlisa/BIOCLIN em amostras sorológicas de 200 cães, em triplicata, incluindo cães sintomáticos, oligossintomáticos e saudáveis, com dois painéis distintos $(A$ e B) caracterizados por testes parasitológicos enquanto referência. No estudo, o kit-protótipo mostrou sensibilidade de 99\% (IC95\%: 94,5-100,0) e especificidade de 100\% (IC95\%: 96,4-100,0). A sensibilidade do kit-protótipo não variou de maneira significativa de acordo com o estado clínico dos cães. Considerando a classificação final dos resultados (positivo ou negativo), a concordância entre os resultados dos testes em triplicata foi quase perfeita (kappa = 0,99; IC95\%: 0,98-1,00). O protótipo ELISA-Vetlisa/BIOCLIN tem o potencial de ser utilizada para o diagnóstico sorológico da leishmaniose visceral canina no Brasil.

Ensaio de Imunoadsorção Enzimática; Leishmaniose Visceral; Cães; Diagnóstico

\section{Resumen}

Los perros son los principales reservorios en el ciclo de transmisión doméstica de la leishmaniasis visceral, por ello el diagnóstico es esencial para la efectividad de las medidas de control recomendadas por el Ministerio de Salud de Brasil. Evaluamos el desempeño diagnóstico de ELISA-Vetlisal BIOCLIN prototipo con muestras de sérum de 200 perros, en triplicado, incluyendo sintomático, oligosintomático, asintomático y perros sanos, originadas por dos paneles distintos $(A y B)$, caracterizados por test parasitológicos como referencia estándar. En este estudio, el kit prototipo mostró un 99\% de sensibilidad (IC95\%: 94,5-100,0) y un 100\% de especificidad (IC95\%: 96,4-100,0). La sensibilidad del kit prototipo no varió significativamente con el estatus clínico de los perros. Considerando la clasificación final del resultado (positiva o negativa), el acuerdo entre los resultados de los tests repetidos fue casi perfecto (kappa =0,99; IC95\%: 0,98-1,00). ELISA-Vetlisa/BIOCLIN tiene potencial para ser usado para el diagnóstico serológico de la leishmaniasis visceral canina en Brasil.

Ensayo de Inmunoadsorción Enzimática; Leishmaniasis Visceral; Perros; Diagnóstico
Submitted on $11 /$ Mar/2020

Final version resubmitted on 23/Jun/2020 Approved on 20/Jul/2020 